\title{
Geografia
} Malaysian Tournal of Society and Space

\section{Maritime border security and challenges for Indonesia}

\author{
Fauzan $^{1}$, Kamarulnizam Abdullah ${ }^{2}$, Mohammad Zaki Ahmad ${ }^{2}$ \\ ${ }^{1}$ Department of International Relations, Universitas Pembangunan Nasional "Veteran" Yogyakarta, \\ Indonesia \\ ${ }^{2}$ College of Law, Government and International Studies, Universiti Utara Malaysia \\ Correspondence: Fauzan (email: fauzan.dj@gmail.com)
}

Received: 15 March 2019; Accepted: 26 April 2019; Published: 14 May 2019

\begin{abstract}
The issue of border security had drawn much attention for being an important part of a country's national security and sovereignty, in addition to its dynamic and complex nature. Indonesia as an archipelagic country faces many problems and challenges in its maritime border areas, in addition to the problems of unresolved state borders with its neighboring countries. Indonesia also faces various trans-boundary crime actions near the maritime border areas. This study aimed at developing a conceptual framework of maritime border security and explaining the challenges of maritime border security. This study applied the qualitative approach by focusing on secondary data. The secondary data were obtained by means of analyses of documents, books, journals, magazines, bulletins and newspaper, including internet sources that were relevant with this study. The findings of this study show that Indonesia faced dynamic and complex problems of maritime border security, not only the problems of unsettled borders with several neighboring countries, but also many transboundary criminal activities in its maritime border areas. The problems of overlapping regulations and institutions added up to the problems to cope with the problems of maritime border security. This study recommends that the government of Indonesia needs to intensify the border diplomacy regarding the maritime borders with the neighboring countries in order to reach delimitation agreements of its maritime border. Further, the government of Indonesia should do immediate reorganization of regulations and institutions of maritime border security to handle all forms of trans-boundary crimes.
\end{abstract}

Keywords: border, limology, maritime border security, neighboring countries, sovereignty, trans-boundary crime

\section{Introduction}

The issue of border security is often an interesting topic of study because it cannot be separated from the national security issues of a country, besides its dynamic and complex nature. The issue of border security is increasingly becoming a concern in many countries, especially after the terrorist attacks on September 11, 2001 in the United States (Alden, 2008; 
Brunet-Jailly, 2007). These events have raised serious attention and raised concerns for many countries regarding their border security (Andreas, 2003). These events have made border security an important element for a country in maintaining and overseeing its border areas, in land, sea and air.

In general, there are several main problems related to maritime border security issues. Among them are overlapping territorial and island claims, regional violations by foreign parties, and cross-border crimes. For most countries around the world, overlapping border claims among neighboring countries are no longer a major issue, but there are still some countries that still face the problem of transnational crimes that threaten not only the sovereignty but also the country's socio-economic development. On the US-Mexico border, for example, the main problems are illegal immigrant and narcotics smuggling (Payan, 2006). The problem of the arrival of illegal immigrants occurs in Western European countries bordering with Eastern European countries (Clochard \& Dupeyron, 2007). Western European countries such as Italy and France also face the problem of illegal immigrants from Africa and the Middle East.

In Southeast Asia, the issue of border security has also received serious attention among the countries in the region. Some forms of security threats still occur frequently, including cases or incidents such as piracy, smuggling and human trafficking, illegal fishing, narcotics smuggling, small arms smuggling, and the spread of radicalism (Clads et al., 2011). Therefore issues related to maritime border security are still crucial in the region. One of the areas that has often been the spotlight of the world is the maritime territorial dispute in the South China Sea involving several countries, namely China, Taiwan, Vietnam, Philippines, Malaysia and Brunei Darussalam. Although Indonesia is not a country involved in the conflict over the territory in the South China Sea, problems arise when China (People's Republic of China) incorporates parts of Indonesia's Natuna waters into China's nine dashes lines.

The problems above show that the issue of maritime border security is still a serious concern for governments in many countries, because it involves the integrity of a country's sovereignty. Maritime border security involves activities not only around the maritime border areas, but also on the boundary line. This paper intended to explain the security problems of the maritime border, the conceptual framework of border security and the challenges the issues of maritime border security pose for Indonesia.

\section{Literature review}

Scholars haven't widely used the concept of maritime border security. This concept can lead to debates related to its meaning and focus, whether border security with a locus in the maritime/ sea or maritime security with a locus at the border. Therefore, it is necessary to explain the two existing concepts, namely border security and maritime security.

Until now, there has not been a precise and comprehensive definition of the concept of border security and maritime security. To facilitate understanding of the conceptual framework of the position of the concept of border security and maritime security in the context of security studies, Buzan et al. (1998) analytical framework regarding the concept of security in maintaining national interests and sovereignty can be used to explain the framework. The concepts of border security and maritime security lie at the intersection of interaction of two group thinking groups, namely traditional security and non-traditional security groups. Traditional security groups are more likely to limit the concept of security (de-securitization) and focus on what are threatened (referent objects), namely sovereignty 
and state identity, whereas non-traditional security groups tend to expand the concept of security (securitization) and have a very wide security landscape about what are meant by security problems (Keliat, 2009).

Brown (2003) supported Buzan et al. (1998) opinion on security by describing the differences in these security groups. The traditional group defines security issues as security search activities by the countries and the competition between countries for security. According to this group, security landscape is the main problem between countries (interstate problems). Whereas, according to non-traditional groups, landscapes declared by traditional groups are insufficient and must include intra-state security problems and cross-national security problems (transnational security problems). Brown (2003) argued that there needs to be a shared understanding of security issues, namely the problems of violent conflicts originating from military and non-military factors, and the understanding of the security arena, whether interstate, intrastate and transnational.

Border problems are always a crucial and strategic issue for a country. The border is a line that separates regions where the state can carry out its sovereignty in full. The border not only separates the territory owned by the state, but also ensures the security of every state (Caflish, 2006). In the context of a nation, borders are a basic element of the nation's identity (security), but in the context of a country, borders can be seen as an aspect of state security practices, or security functions (Laitinen, 2003).

Border security is a complex concept, covering aspects of the military, economy, politics, environment, geography, and so on. In more general terms, border security understood as the safety of life support systems and the absence of threats to people's lives and their activities in the border region. In the perspective of a limology (border studies), it is important to identify who is responsible for border security and what is the subject of threats to national borders (Kolossov, 2006). According to Nelson (2010), border security included in a larger category than the term often referred to as homeland security. In the most basic sense, border security:

"...includes safeguarding a state's land, water, and water domains; deterring threats along these borders; and securing all points of entry, which are locations such as seaports, airports, and and border crossings, where officials are stationed to oversee the legal entry and exit of persons and merchandise".

Furthermore, according to Nelson, border security has three main functions, namely: detection, interdiction and deterrence. Detection activities include identifying border crossers (humans and goods) and classifying potential threats. Interdiction involves the strengthening of border security control, for example, by placing border security agencies or placing a number of electronic technologies in the form of sensors and scanners to help improve the efficiency of border control. Interdiction by definition mainly focused on to how to prepare laws and management activities in border areas. Finally, border security implemented deterrence by placing a number of obstacles along the border line to prevent unwanted crossborder mobility, for example by building walls along the border, placing barbed wire or installing other preventive technologies. Border security involves managing the flow of people, vehicles or transportation equipment, and other tangible items that cross the boundaries of a country. This concept can be applied in a variety of different topographic environments, both land and sea, and various threats (illegal human migration, illegal smuggling of goods, human trafficking, illegal fishing, small arms smuggling, etc.).

Besides the concept of border security, there is a concept of border control which is also often used in border security issues. According to Andreas (2003) the purpose of border 
control is to prevent the entry of clandestine transnational actors which is defined as non-state actors operating beyond national borders in matters of violating state laws and those who avoid law enforcement efforts. The important meaning of border policing for access to a region implies the increasing importance of law enforcement in diplomacy and in policy discourse on borders, signalling that more and more countries are formally encouraging safeguards rather than encouraging the traditional security status.

Likewise, the concept of maritime security does not have a clear definition because of the different perspectives in reviewing maritime security. Some scholars such as Bateman (2011) incorporate non-traditional security threats into that definition. However, some other scholars disagree with the inclusion of the threats of environmental damage and illegal fishing into this definition. Archipelagic countries that have a great interest in the riches of maritime natural resources such as Indonesia and the Philippines want a broader definition. These countries want the issues of protecting the marine environment and illegal fishing included in that definition. Meanwhile, countries that have only small water areas such as Thailand and South Korea, are less in agreement with the inclusion of the issue of Illegal, Unreported, Unregulated (IUU) fishing into the scope of the definition of maritime security. Therefore, maritime security can be interpreted differently by individuals, countries, and organizations, depending on the various interests embedded in it.

Maritime security according to Bailet (1999) is defined as "the freedom from threat to national interests in, on, over, and concerning the sea." Maritime security is not just related to the law enforcement in the sea. Maritime security in a wider definition is the sea being the line or the safe area for users and free from threats to the activities to use and make use of the sea. Maritime security is a combination of preventive and responsive measures to protect maritime areas from threats and unlawful actions (Feldt, 2013). Meanwhile, the United States often uses the term maritime security operations and defines maritime security as:

"The creation and maintenance of security at the sea is essential to mitigating threats short of war, including piracy, terrorism, weapons proliferation, drug trafficking, and other illicit activities. Countering these irregular and transnational threats protects our homeland, enhances global stability, and secures freedom of navigation for the benefit of all nations" (Rahman, 2009).

In a military perspective, maritime security focuses on national security in an effort to protect territorial integrity from threats or attacks by enemies or other countries by using military forces to achieve the interests of the country concerned. However, maritime security has expanded its meaning to include broader security issues, especially with regard to emerging threats. The issue of threats to maritime security is currently getting enough attention because of its expanding nature, including the threats of violence (buccaneer, piracy and sabotage and terror of vital objects), threats of navigation (lack and theft of navigation aids), threats of resources (destruction and pollution of the sea and its ecosystem), and threats of sovereignty and law (illegal fishing, illegal immigrants, illegal exploration and exploitation of natural resources including treasure, arms smuggling, timber theft by sea). These issues can disrupt the stability of a country's sovereignty from other countries and non-state actors.

From the two concepts above, the author tried to define maritime border security as the absence of all forms of threats and potential threats as well as disruptions to the maritime boundaries and the maritime border areas of a country in the forms of both military threats and non-military threats. Included in the concept of maritime border security is the existence of outermost islands which become the baseline in determining the maritime boundaries of a country with other countries. The threat of a country's maritime boundary can be in the form 
of over-lapping claims of border areas with neighboring countries or those involving several countries in a region. Whereas the threat to the maritime border area can be illegal activities that occur in the border area of a country or in an area that is still a dispute area/gray area between two or more countries. In some cases, cross-border crimes (illegal fishing, transshipment) are carried out in the dispute area/gray area to avoid supervision of a country's patrol officer.

\section{Methods and study area}

This study applied the qualitative approach by focusing on secondary data as the basis of analysis. The secondary data were collected through a literature study. This type of data was gathered through analyses of books, journal articles, magazines, bulletin and newspaper, including internet sources that were relevant with this study. The data were important in doing the analyses of problems and threats of maritime border security of Indonesia and its neighboring countries. The scope of this study was the period between 2008 and 2014. This period was chosen because there were several incidents and development, which both directly and indirectly influenced the dynamics of Indonesia's maritime border security. This study identified and analyzed the documents which were related with the approach often used by Indonesia to deal with the problems of maritime border security. This study also analyzed documents of regulations and policies issued by the government of Indonesia. The documents were obtained from several institutions, such as Board of Coordination of Sea Security (Badan Koordinasi Keamanan Laut - BAKORKAMLA), National Border Management Authority, Directorate of Supervision of Marine and Fishery Resources, Ministry of Marine and Fishery, and other institutions. These analyses were important to find out the policies in relation to the problems of maritime border security in Indonesia.

\section{Results and discussion}

\section{Indonesia's maritime border security and its challenges}

Indonesia is the largest archipelagic state in the world with a total of 17,508 islands, 81,000 $\mathrm{km}$ of coastline and 5.8 million $\mathrm{km}$ of water. Two-thirds of Indonesia's territory is the sea area. When compared with land areas, the Indonesian maritime region has more borders with neighboring countries. There are 10 countries bordering the Indonesian maritime region, namely India, Thailand, Malaysia, Singapore, Vietnam, the Philippines, the Republic of Palau, Australia, Timor Leste, and Papua New Guinea. In comparison, Indonesia's land borders are only with three countries, namely Malaysia, Papua New Guinea, and Timor Leste, with a border reaching 2,914.1 km (Batara \& Sukadis, 2007; Mabes TNI, 2007). Indonesia's strategic position between the two main oceans of the world, the Indian Ocean and the Pacific Ocean, makes the country geopolitically and geostrategically important in the context of military movements, goods / trade and human movements. Its strategic position also places Indonesia as a center of gravity in the Asia Pacific region (Figure 1). 


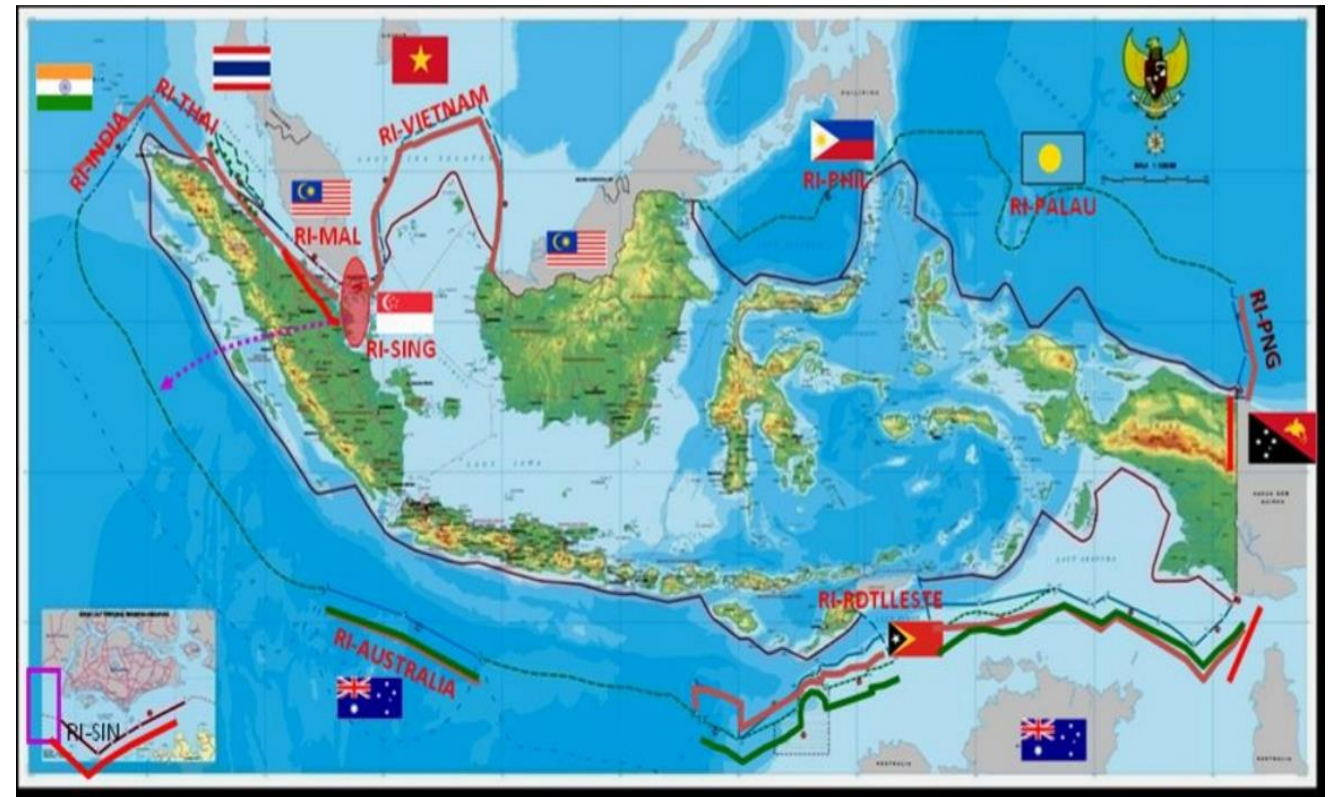

Source: National Border Management Authority Republic of Indonesia, 2011.

Figure 1. The map of the Indonesian territory

With this position, Indonesia can take advantage of the international rules in accordance with UNCLOS 1982 (United Nations Convention on the Law of the Sea) and Indonesia has ratified Law No. 17 of 1985. The Convention came into force as a positive law since 16 November 1994, hence the status of Indonesia as an archipelagic state has been recognized by the international community. The world recognition in the international law authorizes a defined territory for Indonesia, so that Indonesia has legality over its territory, both land, sea and air (Batara \& Sukadis, 2007). Thus, Indonesia has the sovereignty and authority to keep and maintain the integrity of its maritime region, including in managing and regulating the traffic of people and goods between countries by sea, without abandoning the rights of other countries in accordance with the provisions of international laws.

The strategic position of the Indonesian region can also raise its own problems. Most of Indonesia's vast and remote maritime areas, as well as scattered small islands, often make it difficult for the government and related parties to monitor, control and act on all cross-border activities or influences that can disrupt security, regional stability and the integrity of the Republic of Indonesia. In the Indonesian maritime border areas, for example, incidents often occur involving state and non-state actors who engage in violations of national and international laws. These activities can be grouped into four threats, namely (i) violence threats, namely threats using organized armed forces, including: piracy, acts of terror, and sabotage; (ii) threats to natural resources (natural resources tribulation), in the form of pollution and destruction of marine ecosystems and conflicts over management of marine resources that are politicized and followed by deploying military power; (iii) legal violations (law transgression threats); namely the non-compliance with the provisions of national and international laws that apply in the waters, including: illegal fishing, illegal logging, and smuggling; and (iv) navigational hazards, namely the threats posed by the geographical conditions of the maritime and hydrography due to inadequate navigation aids, which could jeopardize the shipping security (Anon, 2012). The Table 1 below shows some forms of violations that occur in the Indonesian maritime border regions. 
Table 1. Violations of Maritime Borders in Indonesia Period of 2009-2012

\begin{tabular}{lcccc}
\hline \multirow{2}{*}{ Forms of violations } & \multicolumn{4}{c}{ Years } \\
\cline { 2 - 5 } & $\mathbf{2 0 0 9}$ & $\mathbf{2 0 1 0}$ & $\mathbf{2 0 1 1}$ & $\mathbf{2 0 1 2}$ \\
\hline Sovereignity violations & 27 & 45 & 27 & 17 \\
Illegal fishings by foreign ships & 167 & 183 & 73 & 159 \\
Violations of laws at sea & 896 & 672 & 605 & 482 \\
(smuggling, illegal mining, etc.) & & & & \\
\hline
\end{tabular}

Source: Anon, 2012.

Even though Indonesia does not face serious border conflicts in the form of armed conflicts with neighboring countries, a number of Indonesian territories bordering with neighboring countries still have a number of problems with territorial claims, in which every party concerned believes having a firm legal standing. In fact, sometimes there are a number of incidents of maritime border violations, both those carried out by civilians such as fishermen and security forces of each country, such as incidents of arrest of Marine and Fisheries Resources Supervision, Ministry of Maritime Affairs and Fisheries (PSDKP KKP) by Malaysian Royal Army (TDM) in Tanjung Berakit, Bintan, Riau Islands last August 2010 (Kompas Online, 2014). Another example is the case in the North Natuna Sea region on June 23, 2010, where there were arrests of Chinese fishing vessels by Indonesian PSDKP patrol boats which then forced the Chinese government to send two fully armed army patrol boats to free citizens and PSDKP patrol boats (Jakarta Greater Online, 2014). A similar case occurred again on March 26, 2013 when a Chinese fishing boat with a hull number 58081 and a capacity of 150 GT (gross tonnage) was captured by the 001 Tiger Shark PSDKP patrol boat in the waters of the North Natuna Sea. But later, the Chinese fishing boat was forced to be released again because a Chinese patrol boat threatened to shoot a PSDKP patrol boat if the ship and its crews were not released (Dupont \& Baker, 2014).

In addition, the vastness of Indonesia's territory bordering with a number of countries can create problems and trans-boundary violations. Many cross-border violations occur in Indonesia's maritime border areas, among others, illegal immigrants, human trafficking, illegal fishing, illegal logging, small arms smuggling, drugs trafficking, oil smuggling, illegal surveys, and so on. In addition to cross-border violations that occur in the maritime border regions, Indonesian waters still leave overlapping maritime territorial claims with a number of neighboring countries.

\section{Maritime border security governance: Sector problems}

One of the problems related to maritime border security is the number of institutions involved in handling maritime security, those of which are not well integrated. In terms of the management, maritime border security still leaves a lot of problems, in terms of institutional and coordination aspects, legal aspects, and aspects of human resources.

To improve coordination among the government institutions in the field of maritime security, in 2003, through the Decree of the Coordinating Minister for Politics and Security (Menkopolkam), No. Kep. 05 / Menko / Polkam / 2/2003, a Planning Working Group on the Development of Security and Law Enforcement in the Sea has been established, then on 29 December 2005, Presidential Regulation No. 81 of 2005 concerning the Sea Security Coordination Agency (BAKORKAMLA) was issued in which Bakorkamla is a non-structural institution that is under and holds responsibility to the President. As a coordinating body, Bakorkamla has several members namely (i) Ministry of Foreign Affairs; (ii) Ministry of Home Affairs: (iii) Ministry of Defense; (iv) Ministry of Law and Human Rights; (v) 
Ministry of Finance; (vi) Ministry of Transportation; (vii) Ministry of Maritime Affairs and Fisheries; (viii) Attorney General; (ix) Commander of the Indonesian Armed Forces (TNI); (x) Police (POLRI); (xi) State Intelligence Agency (BIN); and (xii) Navy Chief. In conducting joint operations, the Marine Security Coordination Task Force (Satgas Korkamla) was formed which is ad hoc.

Then in 2015, Bakorlamla was transformed into the Marine Security Agency (Badan Keamanan Laut - BAKAMLA) after the issuance of Presidential Regulation No. 178 of 2014 concerning the Maritime Security Agency. The presence of Bakamla is expected to be able to anticipate the overlapping of authority in law enforcements in the sea which was originally carried out by many institutions or known as the multi agency multi task to be a single agency multi task in securing Indonesia's maritime area. However, in its implementation Bakamla still leaves problems due to the lack of harmonization and synchronization with other sectoral laws (Pusat Studi Pancasila, 2015).

In securing Indonesia's marine areas, the Navy plays an important role. As an Indonesian archipelago, the Indonesian Navy has a big role in securing and controlling territorial waters of Indonesia. Indonesian Navy according to Law No. 34 of 2004 article 9, has the duty to: (i) carry out the duties of the navy in the maritime affairs in the field of defense; (ii) enforce the law and maintain security in the marine area of national jurisdiction in accordance with national legal provisions and ratified international laws; (iii) carry out the duties of Navy diplomacy in order to support foreign policies set by the government; (iv) carry out the duties of the navy in the construction and development of the power of the sea dimension; and (v) implementing the empowerment of sea defense areas.

The tasks of the Navy as described above can be divided into three functions, namely military functions, diplomacy functions, and law enforcement functions (constabulary functions). These three functions by Ken Booth are known as the concept of "the Trinity of Navy Functions" (Ken Booth, 977). The defense function can be seen from the task of carrying out military operations for war, in accordance with the Army Law (2004) Article 7 paragraph (2b). While the function of diplomacy is regulated in Article 9 (c) of the Army Law, namely the function of diplomacy in accordance with foreign policy inherent in the role of the Indonesian Navy universally in accordance with international customs, and has become the nature of every warship. The function of law enforcement in the sea is in accordance with the authority of the Indonesian Navy (constabulary function) which is universally applicable and in accordance with applicable legal provisions to deal with threats, acts of violence, threats of navigation, and violations of laws in marine jurisdictions. The law enforcement carried out by the Indonesian Navy is limited in the scope of pursuits, arrests, investigations, and case investigations which are then submitted to the prosecutor's office (Susanto \& Munaf, 2015).

Besides Bakamla and the Navy, there are still several other institutions being involved in handling the maritime border areas, namely the coast guard, the task force of the Directorate General of Marine Resources and Fisheries (Satuan Tugas Pengawasan Sumber Daya Kelautan dan Perikanan - Satgas PSDKP) Ministry of Maritime Affairs and Fisheries, the task force for the Sea and Coast Guard Unit (Satuan Tugas Kesatuan Penjagaan Laut dan Pantai - Satgas KPLP) of the Ministry of Transportation and the Customs and Excise Task Force of the Ministry of Finance.

Of the six institutions above, only the Navy and the PSDKP task force can conduct operations up to the EEZ area, while other institutions can only carry out operations in the territorial sea (12 miles). The operational area of each institution can be seen in the Table 2 below. 
Table 2. Maritime areas of operation of the institutions concerned

\begin{tabular}{lccc}
\hline Institution & Territorial Sea & EEZ & Continental shelf \\
BAKAMLA & $\checkmark$ & $\checkmark$ & $\checkmark$ \\
Navy & $\checkmark$ & & \\
Coast Guard & $\checkmark$ & $\checkmark$ & \\
PSDKP & $\checkmark$ & & \\
KPLP & $\checkmark$ & & \\
Customs & $\checkmark$ & & \\
\hline
\end{tabular}

From the Table 2, it can be seen that there are six institutions that have authority related to law enforcement and have patrol boats to carry out tasks in the territorial waters, namely Bakamla, Indonesian Navy, Coast Guard, PSDKP Task Force, KPLP Task Force and Customs Task Force. The Navy has the authority to carry out operations in all waters, both territorial sea, continental shelf and EEZ. The PSDKP Task Force can carry out operations in territorial sea waters up to EEZ, while other institutions such as the Water Police, KPLP task force and Customs task force can only carry out operations in the territorial sea areas.

Although there are many institutions involved in the management of maritime border security, the implementation of security of maritime borders and outermost small islands tends to be not integrated, because the institutions in carrying out law enforcement efforts still bases their measures on their respective institutions' laws and regulations. Legal framework that becomes the basis for securing the maritime borders has not been sufficient. Even so, there are basic regulations that we can refer to, such as Law No. 34/2004 on Indonesian Army, Law No. 32/2014 on Marines and Law No. 17/2008 on Shipping. They specifically assert the importance of creating a marine defense system and the obligation to report every activity that brings dangers to shipping. Nevertheless, those legal instruments do not specifically explain a mechanism to fight marine criminal activities (Dinarto, 2017), whereas the mechanism is important to create a system of maritime border security that integrate the relevant institutions.

So far, the organization of maritime border areas has been carried out partially and adhoc by many institutions, both at the central and regional levels. This situation makes the management of maritime border areas ineffective in overcoming problems at complex maritime borders. Overlapping tasks and functions between institutions, lack of coordination of institutions in managing border areas are still common. This situation certainly can lead to errors in the field due to the parties having different interpretations regarding the implementation of the authority possessed by each institution, as mandated by laws.

\section{Conclusion}

Indonesia still faces problems of dynamic and complex maritime border security in the forms of unsettled border agreements with several neighboring countries and many trans-boundary crimes in the maritime border areas. Furthermore, there has not been an institution that integrates many institutions that run the functions and roles to secure the maritime borders. There are many institutions that deal with the security of maritime borders with reference to regulations on various individual sectors. The activities in conducting their respective roles often overlap and cause frictions among the institutions due to their strong sectoral egos.

Therefore, the government of Indonesia needs an immediate agenda in the future to intensify the border diplomacy in relation to the maritime borders with neighboring countries to reach the agreements on the delimitation of its maritime borders. Additionally, the government of Indonesia needs to immediately reorganize the regulations and institutions of 
maritime border security in Indonesia to deal with all forms of trans-boundary criminal activities that can bring harm to the country. The reformation of management of maritime border security in Indonesia is necessary considering the complexity of border issues.

\section{Acknowledgement}

This article was supported by UUM-PBIT No. S/O: 12876.

\section{References}

Alden, E. (2008). The closing of the American border: Terrorism, immigration and security since $9 / 11$. New York, Harper Collins Publishers Inc.

Andreas, P. (2003). Redrawing the line: Borders and security in twenty-first century. International Security, 28(2), 78-111.

Anon. (2012). Penataan pengamanan wilayah maritim guna memelihara stabilitas keamanan dalam rangka menjaga kedaulatan NKRI, Jurnal Kajian Lemhannas RI, 14, December.

Bailet, F.N., \& Crickard, F.W. (1999). Integrated maritime enforcement: A handbook (pp. 9). Msifax, Dalhousie University Press.

Batara, A., \& Sukadis, B. (Eds.). (2007). Reformasi Manajemen Perbatasan di NegaraNegara Transisi Demokrasi. Jakarta, DCAF-LESPERSSI.

Bateman, S. (2011). Solving the 'Wicked problems' of maritime security: Are regional forums up to the task? Contemporary Southeast Asia, 33(1), 1-28.

BNPP RI (2015). Rencana induk pengelolaan perbatasan negara tahun 2015-2019, Jakarta, Badan Nasional Pengelola Perbatasan.

Booth, K. (1977). Navies and foreign policy (pp. 15). London, Taylor \& Francis.

Brown, M.E. (2003). Grave new world: Security challenges in the $21^{\text {st }}$ century (pp. 305-325). Washington, Georgetown University Press.

Brunet-Jailly, E. (2007). Boderlands: Comparing border security in North America and Europe (pp. 1-18). Ottawa, University of Ottawa Press.

Brunet-Jailly, Emmanuel (eds.). Borderlands: Comparing border security in North America and Europe (pp. 19-40). Ottawa, University of Ottawa Press.

Buzan, B., Waever, O., \& de Wilde, J. (1998). Security: A new framework for analysis. Colorado, Lynne Rienner Publisher.

Caflish, L. (2006). A typology of border. Retrieved from www.dur.ac.uk/resources/ibru/conferences/thailand/caflish.pdf.

Clad, J., Mc Donald, S.M., \& Vaughn, B. (Eds). (2011). The borderlands of Southeast Asia: Geopolitics, terrorism and globalization (pp. 107-126). Washington, National Defense University Press.

Clochard, O., \& Dupeyron, B. (2007). The maritime borders of Europe: Upstream migratory controls. In Brunet-Jailly, Emmanuel (eds.), Borderlands: Comparing border security in North America and Europe (pp. 19-40). Ottawa, University of Ottawa Press.

Decree of Coordinating Minister of Politics and Security (Menkopolkam) No. Kep. 65/Menko/Polkam/2/2003.

Dinarto, D. (2016). Reformasi tata kelola keamanan maritim Indonesia di era Presiden Joko Widodo. Retrieved from https://www.researchgate.net.

Dupont, A., \& Baker, C.G. (2014). East Asia's maritime disputes: Fishing in troubled waters, The Washington Quarterly, 37(1), 85-86. 
Feldt, L. (2013). Maritime security - Perspectives for a comprehensive approach, ISPSW Strategy Series: Focus on Defense and International Security, Issue No. 222, April, 2.

Keliat, M. (2009). Keamanan maritim dan implikasi kebijakannya bagi Indonesia. Jurnal Ilmu Sosial dan Ilmu Politik, 13(1), 111-129.

Kolossov, V. (2006). Theoritical limology: Postmodern analytical approaches, Diogenes, 53(2), 11-22.

Kompas Online. (2010). Kronologi penangkapan tiga petugas DKP. Retrieved from iga. http://regional.kompas.com.

Laitinen, K. (2003). Geopolitics of the Northern dimensions: A critical view of border studies, Geopolitics, 8(1), 20-44.

Law No. 17/1985.

Law No. 32/2014.

Law No. 34/2004.

Law No. 43/2008.

Mabes TNI (2007). Buku petunjuk pelaksanaan TNI tentang operasi pengamanan perbatasan (pp. 1). Jakarta, Mabes TNI.

Madu, L., Loy, N., Nugraha, A., \& Fauzan. (Eds). (2012). Mengelola perbatasan Indonesia di dunia tanpa batas: Isu, permasalahan dan pilihan kebijakan (pp. 5). Yogyakarta, Graha Ilmu.

Nelson, R. (2010). Border security in a time of transformation: Two international case studies-Poland and India, A report of the CSIS Homeland Security \& Counter Terrorism Program, Europe Program and South Asia Program, July, 5-10.

Payan, T. (2006). The three US-Mexico borders war: Drugs, immigration and homeland security, Westport, Praeger Security International.

Presidential Regulation No. 178/2014.

Presidential Regulation No. 81/2005.

Pusat Studi Pancasila (2015). Membangun kedaulatan bangsa berdasarkan nilai-nilai pancasila: Pemberdayaan masyarakat dalam kawasan terluar, terdepan dan tertinggal (3T), Yogyakarta, Pusat Studi Pancasila UGM, 451.

Rahman, C. (2009). Concept of maritime security: A strategic perspective on alternative visions for good order and security at sea, with policy implications for New Zealand, Discussion Paper No. 07/09, New Zealand, Centre for Strategic Studies, 30.

Susanto, \& Munaf, D.P. (2015). Komando dan pengendalian keamanan dan keselamatan laut: Berbasis sistem peringatan dini (pp. 53). Jakarta, PT. Gramedia Pustaka Utama. 